\title{
Analyses and Findings of Unusual Substitute Materials in a Raincoat From WWII
}

\section{Clara Bratt Lauridsen ( $\boldsymbol{\sigma}$ cbl@konsvejle.dk)}

Conservation Centre Vejle: Center for Bevaring af Kulturarv Konserveringscentret https://orcid.org/0000-0002-8009-7644

\section{Theis Brock-Nannestad}

University of Copenhagen Department of Chemistry

Kim Pilkjær Simonsen

Conservation Centre Vejle: Center for Bevaring af Kulturarv Konserveringscentret

\section{Research Article}

Keywords: Rayon staple fibers, Paper yarn, cellulose nitrate lacquer, Poly(1,3-butylene) adipate, Buna, IG Farben

Posted Date: June 4th, 2021

DOI: https://doi.org/10.21203/rs.3.rs-576379/v1

License: (1) (1) This work is licensed under a Creative Commons Attribution 4.0 International License. Read Full License

Version of Record: A version of this preprint was published at Heritage Science on September 15th, 2021. See the published version at https://doi.org/10.1186/s40494-021-00572-7. 


\section{Analyses and findings of unusual substitute materials in a raincoat from WWII}

Clara Bratt Lauridsen ${ }^{1 *}$, Theis Brock-Nannestad ${ }^{2}$, and Kim Pilkjær Simonsen ${ }^{1}$

*Corresponding author: cbl@konsvejle.dk

${ }^{1}$ Conservation Centre Vejle, Maribovej 10, DK-7100 Vejle, Denmark.

${ }^{2}$ Department of Chemistry, University of Copenhagen, Universitetsparken 5, DK-2100 Copenhagen $\varnothing$, Denmark.

Theis Brock-Nannestad

Kim Pilkjær Simonsen brock-nannestad@chem.ku.dk

kps@konsvejle.dk 


\begin{abstract}
Due to the coating materials used, historic raincoats are vulnerable to degradation and rarely survive long periods of time. The investigated raincoat dating from 1943 is no exception - the coating is unusually stiff and flaking off in areas around folds and cracks. Study into its material composition can contribute to important knowledge of the availability of materials for waterproof clothing during the time of the German occupation of Denmark (1940-1945) when the usual materials for raincoats, cotton fabric and rubber, were in short supply. Optical microscopy and attenuated total reflectance-Fourier transform infrared spectroscopy (ATR-FTIR) identified the fabric to consist of rayon stable fibers and paper yarn, and the coating to be based on cellulose nitrate $(\mathrm{CN})$ lacquer, an unknown plasticizer and titanium white $\left(\mathrm{TiO}_{2}\right)$. Though the results are atypical for a raincoat, they are in good accordance with the raw materials available in Denmark in 1943. Analysis by matrixassisted laser desorption-ionization mass spectrometry (MALDI-MS), and ${ }^{1} \mathrm{H}$ and ${ }^{13} \mathrm{C}$ nuclear magnetic resonance spectroscopy (NMR), identified the plasticiser as poly(1,3-butylene) adipate. Powder X-ray diffraction (PXRD) moreover identified the titanium white pigment as the anatase form. By historical discussion this study argues that IG Farben AG is the likely producer of poly(1,3-butylene) adipate, even though the first known marketing of the plastiticiser is from 1986 where the Swiss firm Ciba-Geigy introduced poly(1,3-butylene) adipate as a plasticiser for PVC cling films under the tradename Reoplex ${ }^{\circledR} 346$. The finding is an extraordinary example on how advanced the chemical industry was in the early 1940's when it came to polymer science.
\end{abstract}

\title{
Keywords
}

Rayon staple fibers, Paper yarn, cellulose nitrate lacquer, Poly(1,3-butylene) adipate, Buna, IG Farben 


\section{Introduction}

When Denmark was occupied by Germany on 9 April 1940, the country was immediately cut off from other countries that traditionally had supplied a great deal of raw materials. Denmark became dependent on trade that in many ways, was adapted to the German needs [1].

During the five-year period of the German occupation, many substitute products were traded, which had not been traded before and did not continue to be traded after WWII when raw materials were available again. Many of these substitute products were experimental and often created to fulfill immediate needs. Many of them were made with relatively short-lived materials, or materials that were not made for the task in the first place. As such, items which have managed to survive until today are typically in a poor condition. However, they should be considered an important testimony of that time, and give a first-hand insight in the creative handling of the scarce resources available. A woman's fashion raincoat from Glud Museum, Denmark, dating from 1943 is no exception (Fig. 1). The raincoat, about $100 \mathrm{~cm}$ long, is made of a rather coarse and relative open weave material that can be seen clearly through the light, beige colored coating (Fig. 1a). The raincoat has a dog collar, snap fasteners made of metal, a belt and metal eyelets under the armpits to allow for ventilation. Inside, the raincoat is provided with the number " 100 " and a trademark that is smeared and barely readable (Fig. 1b). Today the raincoat is unusually stiff and the coating is flaking off around areas of folds and cracks.

The raincoat was originally purchased by the clothing store AI Hansen in Vejle, probably with the intention of resale. AI Hansen sold mainly knitwear and yarns but during the occupation, other products were sold as well, often in order to fill the shelves (Fig 2). In particular baby carriages were selling well [2]. It is feasible that the raincoat was being marketed at mothers, in order to look fashionable when out for a stroll with the baby carriage during a light summer rain? However, the raincoat was never sold, but stored in the loft of the store until it was given to the open-air Museum 
in Glud in 1989.

The grandchild of the founder of AI Hansen, Anders Jørgen Hygebjerg-Hansen, who took over the store in 1966, mentions the raincoat in his memories: "Then comes WWII with a shortage of goods (...) A raincoat made of paper yarn, which was lacquered to become waterproof, did we keep for long in memory of that time. Now it is at Glud Museum" [2].

As the quote from Hygebjerg-Hansen suggests, being able to provide women's fashion rainwear during the occupation must have been much of a challenge. Up until the occupation, the most popular women's rainwear in Denmark was rubber coats. Other kinds of rainwear such as impregnated coats and oil skins, were mainly for men's rainwear and workwear [3]. Rubber was in scarce supply and reserved mainly for the tires and tubes of bicycles [1,4]. Moreover, during the occupation, Denmark was cut off from the most important fiber for textile, cotton [1].

Using various state-of-the-art analytical techniques, this study investigated the raw materials of the raincoat and looked at their availability in Denmark during the occupation period. Of all clothing, raincoats are some of the most vulnerable and complex, due in particular to the coating materials, which are often prone to degradation [5]. Raincoats from the war period, produced with nontraditional materials during a very resource-limited time, are extremely rare. However, they constitute an interesting study on the availability of materials and the creativity of the textile industry in a time of restrictions.

\section{Experimental}

\section{Samples}

A sample of the coated fabric was cut out from a seam allowance from the inside of the raincoat, and a small sample of the lifting coating was carefully taken from the outside. 


\section{Extraction and separation}

The sample cut from the seam allowance was covered with chloroform to extract the plasticiser from the cellulose nitrate $(\mathrm{CN})$ coating lacquer (see results section below) as $\mathrm{CN}$ is insoluble in chloroform. The fabric was then washed free of $\mathrm{CN}$ lacquer with ethyl acetate, and the weft and warp yarn separated and examined. The solution of the $\mathrm{CN}$ lacquer in ethyl acetate was centrifuged to separate the $\mathrm{CN}$ from the inorganic pigment. After evaporation of the solvents, the extracts were analysed.

\section{Optical microscopy}

The fibers were studied under transmitted light with a Leica DMRB optical microscope with magnifications up to $200 x$.

\section{ATR-FTIR}

Spectra were recorded on a Nicolet iS5 FTIR-spectrometer from ThermoFisher Scientific, equipped with an attenuated total reflectance (ATR) unit with a monolithic diamond crystal. Spectra from the samples were recorded in the range from $4000-650 \mathrm{~cm}^{-1}$ with a spectral resolution of $4 \mathrm{~cm}^{-1}$ and 4 accumulations. The spectra were then compared with spectral reference data in the database of OMNIC and OMNIC SPECTRA.

\section{NMR}

NMR measurements $\left({ }^{1} \mathrm{H},{ }^{13} \mathrm{C}\left\{{ }^{1} \mathrm{H}\right\}\right.$, and $\left.{ }^{1} \mathrm{H}-{ }^{1} \mathrm{H} \mathrm{COSY}(\mathrm{GP})\right)$ were carried out using a $500 \mathrm{MHz}$ Bruker instrument with a cryoprobe. $\mathrm{CDCl}_{3}$ solvent signals were used for calibration $\left(\mathrm{CDCl}_{3}: 7.26\right.$ and $77.16 \mathrm{ppm}$ for ${ }^{1} \mathrm{H}$ and ${ }^{13} \mathrm{C}$, respectively). 


\section{MALDI-MS}

MALDI MS were recorded on a Bruker Solarix XR 7T ESI/MALDI-FTICR-MS instrument operating in reflectron positive ion mode. Dithranol spiked with sodium trifluoroacetate (NaTFA) was used as MALDI-matrix, and external calibration was performed with NaTFA cluster-ions from the ESI source. MALDI excitation was carried out with a Bruker SmartBeam-II $355 \mathrm{~nm}$ laser running at $15 \%$ power. Spectra were recorded at $150-4000 \mathrm{~m} / \mathrm{z}$ using small spot-size at a frequency of $200 \mathrm{~Hz} .20$ laser shots were used at each spot, with the XY-table being moved in raster mode.

\section{PXRD}

PXRD-analyses were performed with a Bruker D8 Advance diffractometer using Ni-filtered $\mathrm{Cu}-\mathrm{K} \alpha$ radiation $(\lambda=1.54056 \AA)$ and a Lynxeye position sensitive detector in the range $2 \theta=5-70^{\circ}(\Delta 2 \theta=$ $0.01^{\circ}$ ) with a total exposure time of 8 hours. A thin layer of material was deposited directly on the Si monocrystal zero-background plate and measured at ambient temperature.

\section{Results and Discussion}

\section{The fabric}

The fabric is woven in plain weave and consists of a relatively thin, white warp with some distance between every second yarn, and a broader, brown weft (Fig. 1b). By opening and untwisting a sample of the weft yarn with a preparation needle, the material was easily identified as paper yarn as expected from the description of Hygebjerg-Hansen. The unfolded sample consisted of a brown paper strip of approximately $5 \mathrm{~mm}$ in width. The warp was identified as regenerated cellulose fiber (Rayon) by FTIR. FTIR is a suitable method to tell the difference from natural cellulose, due to its sensitivity towards differences in crystallinity and crystal lattice. An important difference between 
the natural cellulose and the regenerated ones, is the practically non-existence of crystalline cellulose of lattice type I in the latter, whereas both contain lattice type II and amorphous cellulose. The absence of type I in the regenerated cellulose can be seen in the FTIR spectrum Fig. 3 (compared with the spectrum of paper yarn) by the absence of the band at $1104 \mathrm{~cm}^{-1}$, and a shift and lowering of intensity in the band at $1427 \mathrm{~cm}^{-1}\left(\mathrm{CH}_{2}\right.$ symmetric bending $)$ to $1420 \mathrm{~cm}^{-1}$ [6, 7]. It is likely that the yarn consisted of staple fibers (and not filament fibers), that can be recognized by the relatively high number of loose fiber ends sticking out of the yarn. Under the microscope, the characteristic longitudinal striations of viscose Rayon fibers were recognized (absent in the fibers of the less produced copper Rayon) [8]. The fibers are loosely Z-spun into a two-ply yarn with an Stwist.

\section{The coating}

The sample from the lifting coating was analysed by FTIR on both sides. Only minor differences were seen between the two spectra, which most likely relates to contamination of the underside of the sample with the paper fiber of the fabric, rather than true differences between the top and underside of the coating. The spectrum of the topside of the sample, and of the extracted and separated coating materials are shown in Fig. 4. In the top spectrum of Fig. 4 (topside of the sample), characteristic bands at 1637 and $1274 \mathrm{~cm}^{-1}$ (asymmetric and symmetric $\mathrm{NO}_{2}$-stretch), 833 $\mathrm{cm}^{-1}$ (N-O stretch) $1058 \mathrm{~cm}^{-1}$ (C-O stretch), indicates the presence of cellulose nitrate (CN) [9]. Absorption at $1714 \mathrm{~cm}^{-1}$ relates to the carbonyl-band of the plasticizer, whereas strong absorption towards lower wavenumbers, around $750 \mathrm{~cm}^{-1}$, indicate the presence of titanium dioxide white [10]. The FTIR-spectrum of the clear fluid plasticiser (extracted with chloroform as described in the experimental section) is shown in Fig. 4, middle spectrum. The carbonyl band at $1726 \mathrm{~cm}^{-1}$ in combination with C-O stretching vibrations at 1173 and $1137 \mathrm{~cm}^{-1}$, reveals the presence of an ester, 
whereas relative strong abortion at $1378 \mathrm{~cm}^{-1}$ reveals a relative high amount of methyl $\left(\mathrm{CH}_{3}\right)$ groups (symmetrical bending vibrations) [11]. The carbonyl band, seen at somewhat lower wavenumbers in the spectrum before extraction, may relate to hydrogen bonds between the carbonyl group of the plasticiser and the $\mathrm{CN}$, thereby causing a shift of the carbonyl absorption to lower wavenumbers in the mixture [12]. It was not possible to identify the plasticiser with FTIR due to the lack of a reference spectrum. The plasticiser was therefore analyzed further by NMR and MALDI-MS.

The ${ }^{1} \mathrm{H}$ and ${ }^{13} \mathrm{C}\left\{{ }^{1} \mathrm{H}\right\}$ NMR spectra of the extracted plasticiser in $\mathrm{CDCl}_{3}$ are shown in Fig. 5, together with a drawing of the structure of the two major diol-terminated species i.e. primary and secondary alcohol, and the molecule numbering scheme used for the characterisation. Both NMR spectra are in full accordance with the thorough NMR spectrometric analysis $[13,14]$ of the commercial plasticiser Reoplex ${ }^{\circledR} 346$ from Ciba-Geigy, which thereby identify the plasticiser as poly(1,3butylene) adipate.

Integration of the areas of the hydrogen atoms neighboring the primary alcohol in the in-chain esterified primary alcohol (5), and of its two possible mono-esterified end-groups i.e. (5') from the primary alcohol esterification, and $\left(5^{*}\right)$ from the secondary alcohol esterification are shown in Fig. 6. The low ratio of $c .3$ indicates both that the diol-terminated oligomers are dominant species, and that the poly(1,3-butylene) adipate oligomers are of relatively short length. Also given in Fig. 6 is the ratio between the primary alcohol esterification end-group, and the secondary alcohol esterification end-group based on $\left(5^{\prime}\right)$ and $\left(5^{*}\right)$. As can be seen from the ratio of 2.75 , the amount of free secondary alcohol in the chain-ends is greater than primary due to higher esterification reactivity of the primary alcohol.

In order to determine the oligomer chain length of the plasticiser MALDI-MS was performed as shown in Fig. 7 with insert of enlarged area of 1000 to $1500 \mathrm{~m} / \mathrm{z}$ units. Interpretation of the 
oligomer repeat units (n) is shown in Fig. 8, where drawings of the structural assignments based on poly(1,3-butylene) adipate and molecular weights with addition of sodium ion $\left(\mathrm{M}+\mathrm{Na}^{+}\right)$are given . As seen from the MS spectrum (Fig. 7) and Fig. 8, the major amount of oligomers are present with $\mathrm{n}=4-9$. This low value polymerization, and hence low average molecular weight, are in accordance with the investigation of Reoplex ${ }^{\circledR} 346$ which was published in 1991 and 2000, respectively [13, 14].

It is, however, interesting that Ciba-Geigy first announced the presence of Reoplex ${ }^{\circledR} 346$ to the market in 1986 [15] but analysis of WWII polymeric materials revealed the presence of this type of plasticiser much earlier.

\section{Pigment}

The PXRD pattern of the titanium white pigment is shown in Fig. 9 and identifies it as the anatase form of $\mathrm{TiO}_{2}$. Titanium white pigments, which have been produced on a commercial scale since 1918, were appreciated in particular because of their bright color, opacity and non-toxic character [10]. Most notable of this finding, is the lack of a substrate or filler like barium sulfate or calcium sulfate, which was typically always part of the early titanium white pigments. The pure form of anatase was developed in the early 1920's, but the price was far higher than that of the composites [16], with the pure form first gaining importance as a pigment in the 1940's [17].

\section{Historic discussion}

\section{The textile}

Of the two fibers identified in the raincoat, the regenerated cellulose fibers, also called Rayon staple fibers, or just staple fibers, were of greatest importance in the textile industry for clothing during WWII. At that time, the most common way to make Rayon was by the viscose method, whereby a 
refined wood pulp was commonly used as raw material. By treating the wood pulp with chemicals, it was converted to a xanthate derivative and solubilized to a viscous liquid (the viscose). Extruded through spinnerets into a coagulation bath and rinsed free of chemicals, the viscose was converted into white cellulosic fibers that were either wound up on spools as Rayon filament fibers (used in particular for artificial silk) or cut in discrete lengths and further treated to spin well (the Rayon staple fibers) $[18,19]$.

The production of staple fibers in Germany in the 1930's and during WWII was strongly influenced by the Nazi autarkic politics. Autarky meant as far as possible to be self-sufficient in raw materials and not to depend on import. The textile industry, with its high level of imported raw materials such as cotton and wool, was a particularly challenging sector in this respect. Staple fibers, able to be produced from domestic wood and chemicals readily available, became extremely attractive [20, 21].

The use of staple fibers in Denmark was quite modest until the German occupation in 1940. With one stroke, Denmark was cut off from its cotton suppliers, and staple fibers soon became its most important substitute [1]. Similar to staple fibers, the use of paper yarn strongly increased during the occupation period in Denmark, in particular to replace the previously imported fibers; jute and hemp [1].

Paper yarn was strong, stiff and inflexible, and often impregnated to resist water. It was used particular for ropes, twine, baling twine, sacks and as a component in webbing [22, 23]. In contrast to staple fibers, the stiffness of the paper yarn did not make it suitable as a substitute fiber in clothing. Its use in clothing during WWI, particularly in Germany, was due to the lack of more appropriate fibers $[23,24]$. The finding in the raincoat would indicate that staple fibers were in short supply, something which is known to have happened during the time from which the raincoat dates. Thus, in 1943, Germany experienced a critical shortage of spinning fibers for the first time since the 
beginning of the war [25]. Moreover, major deliveries of staple fibers to Denmark from Italy ceased after the Fascist regime collapsed in July the same year [1]. Because of the shortage of staple fibers, paper yarn was increasingly used as substitute [1]. Paper was abundantly available in the end of 1943, and did not become scarce before the summer/ autumn of 1944, when Sweden reduced and eventually ceased export of paper to Denmark. The scarcity of both paper yarn and staple fibers in 1944 was countered with an increased production of domestic flax [1, 26].

\section{The coating}

The finding of the $\mathrm{CN}$-lacquer as coating material falls within a time when $\mathrm{CN}$-lacquer was one of the most important lacquers on the market.

The breakthrough of CN lacquer for great industrial use happened in the years after WWI and was mainly driven by improvements in the film forming properties, as well as greater availability of proper solvents $[27,28]$. The fast-drying time made the lacquer particularly attractive for industrial use, and it became indispensable in the fast growing automobile industry [29]. Of particular interest when looking into the use of CN-lacquer during WWII, was the introduction of wood pulp as a raw material in the late 1930's [27]. As described earlier, the use of refined wood pulp already played a major role in the production of staple fiber and Rayon in the textile industry. But it was not until late into the 1930's that the industry managed to produce a wood pulp pure enough to replace cotton as raw material for $\mathrm{CN}$-lacquer [27]. With wood pulp as a raw material, the lacquer production not only survived the cut off of cotton during war-time, but its use expanded to areas where it had not been traditionally used [27]. This also applies to the raincoat, where the water resistance of the CNlacquer, and more importantly, its availability during the occupation, made it a logical choice as a coating material in a time where the most common material for this purpose, rubber, was not available. 


\section{The plasticiser}

Of all the findings pertaining to the raincoat, the plasticiser poly(1,3-butylene) adipate is the most surprising.

The authors found no mention of poly(1,3-butylene) adipate in the plasticiser literature of the time, nor in the patent literature. It is not before 1986, that the Swiss firm Ciba-Geigy introduces poly(1,3-butylene) adipate as plasticiser under the tradename Reoplex ${ }^{\circledR} 346$ for use within PVC cling films, appreciated for its low volatility preventing its migration into food $[15,14]$. It is likely that poly(1,3-butylene) adipate existed in the 1940's under one of the several commercial names that did not disclose the composition of their content at the time [30]. Probably it had been developed for PVC in the first place, exactly like Reoplex more than 40 years later. Perhaps the traditional plasticiser used for flexible $\mathrm{CN}$-coatings, resinous oil [31], was in short supply, similar to other overseas products.

The 1940's saw a rapid development of plasticisers, primarily due to their indispensability for many of the new synthetic polymers that were on the market at that time, in particular PVC. Linear polyester plasticisers (non-cyclic condensation products of dibasic acids and dihydric alcohols), were introduced in 1942 by Rohm \& Hass Laboratories in Philadelphia, as excellent nonvolatile plasticisers for PVC and PVC-acetate $[32,33]$. The finding of this type of plasticiser in the raincoat is thus rather surprising, and indicates that Europe was not behind the USA when it came to their

development. It is remarkable however, that no sources on its early production in Europe seem to be available, and the finding in the raincoat may be the earliest of its kind reported on European ground.

Though no European firm can be connected directly with the plasticiser, there is good reason to 
believe it was produced in Germany and probably by IG Farben AG, which was the leading European firm when it came to polymer science, and the largest chemical company in Europe. IG Farben, the result of a merger in 1925 of leading chemical companies, including Badische Anilin- and Soda-Fabrik (BASF), Bayer and Höchst, began focusing on polymers early on [34, 35], and was one of the first companies worldwide to produce PVC on large scale in 1937 [36, 37]. It is, however, the production of synthetic rubber or Buna, which may connect the plasticier to IG Farben. Buna (acronym for butadiene and Natrium (German for sodium, the catalyst for the synthesis)) was developed by IG-Farben chemists in the late 1920's and was an improvement of earlier synthetic rubber products. In general, the term Buna covers a copolymer of butadiene and styrene (Buna-S). 1,3-butanediol, the one monomer in the plasticiser, was an intermediate in the four-step process (Vierstufen Verfahren) used by IG Farben to obtain butadiene from acetylene [3840]:

$$
\begin{gathered}
\mathrm{CH} \equiv \mathrm{CH}+\mathrm{H}_{2} \mathrm{O} \rightarrow \mathrm{CH}_{3} \mathrm{CHO} \\
2 \mathrm{CH}_{3} \mathrm{CHO} \rightarrow \mathrm{CH}_{3} \mathrm{CHOCH}_{2} \mathrm{CHO} \\
\mathrm{CH}_{3} \mathrm{CHOCH}_{2} \mathrm{CHO}+\mathrm{H}_{2} \rightarrow \mathrm{CH}_{3} \mathrm{CHOHCH}_{2} \mathrm{CH}_{2} \mathrm{OH} \\
\mathrm{CH}_{3} \mathrm{CHOHCH}_{2} \mathrm{CH}_{2} \mathrm{OH} \rightarrow \mathrm{CH}_{2}=\mathrm{CHCH}=\mathrm{CH}_{2}+2 \mathrm{H}_{2} \mathrm{O}
\end{gathered}
$$

As seen above, 1,3-butanediol is the product of the hydrogen reduction of aldol in the third step. The high cost of the four-step process made Buna noncompetitive with natural rubber, and large scale production was only realized as part of the Nazi autarkic politics of the 1930's, culminating with the four year plan of 1936 [41]. Buna was particularly important for the tires of the fastgrowing automobile industry and moreover, indispensable for the clandestine rearmament $[42,38]$. The first Buna factories for large scale production were erected in Schkopau (1939) and Hüls in Marl (1940) [38]. 
In 1937 IG chemist Walter Reppe developed the more profitable three-step process to produce butadiene:

$$
\begin{gathered}
\mathrm{CH} \equiv \mathrm{CH}+2 \mathrm{HCHO} \rightarrow \mathrm{HOCH}_{2} \mathrm{C} \equiv \mathrm{CCH}_{2} \mathrm{OH} \\
\mathrm{HOCH}_{2} \mathrm{C} \equiv \mathrm{CCH}_{2} \mathrm{OH}+2 \mathrm{H}_{2} \rightarrow \mathrm{HOCH}_{2} \mathrm{CH}_{2} \mathrm{CH}_{2} \mathrm{CH}_{2} \mathrm{OH} \\
\mathrm{HOCH}_{2} \mathrm{CH}_{2} \mathrm{CH}_{2} \mathrm{CH}_{2} \mathrm{OH} \stackrel{-\mathrm{H}_{2} \mathrm{O}}{\longrightarrow} \mathrm{C}_{4} \mathrm{H}_{8} \mathrm{O} \stackrel{-\mathrm{H}_{2} \mathrm{O}}{\longrightarrow} \mathrm{CH}_{2}=\mathrm{CHCH}=\mathrm{CH}_{2}
\end{gathered}
$$

As seen above, In the Reppe process or three-step process, 1,3-butanediol was no longer an intermediate product. The three-step process was introduced in the third Buna factory, erected in 1941-1943 at Ludwigshafen. Buna was, however, still produced from the four-step process in the old factories while conversion to the three-step process was not technically possible [38].

The finding of 1,3-butanediol as a monomer in a plasticiser used for a $\mathrm{CN}$-lacquer of a raincoat may seem strange considering how important Buna was for military uses. However, the Buna factories were also involved in the production of polymers and plasticisers $[43,38,44]$. This fact may plausibly explain why an important intermediate product of the Buna industry ended up in a polymeric plasticiser probably developed for the PVC industry.

\section{Conclusion}

This study provides interesting knowledge on the availability of raw materials in Denmark during the German occupation, when many overseas materials like wool, cotton and rubber were scarce in supply. The major importance of wood pulp in the substitution industry is reflected in the fact that this was used as basis for all main materials of the raincoat: The paper and staple fiber yarn of the textile, as well as the $\mathrm{CN}$-lacquer of the coating. In particular, the finding of paper yarn supports the 
dating of the raincoat to 1943 , a year in which this material was increasingly used as a substitute material.

Of particular interest, is the finding of poly(1,3-butylene) adipate as a plasticiser in the cellulose nitrate lacquer coating. The first known description and marketing of this plasticiser is from 1986 where the Swiss firm Ciba-Geigy introduced poly(1,3-butylene) adipate as a plasticiser for PVC cling films under the tradename Reoplex ${ }^{\circledR} 346$. However, this study suggests that the plasticiser was developed much earlier in Germany by IG-Farben, likely due to the relation of 1,3-butanediol in its Buna production. The finding is also interesting in other aspects as it shows that intermediate chemical products of the war industry were re-directed into civilian end-products.

It is likely that many chemical advancements and experiments that took place up to, and during WWII may have been forgotten in the chaotic final years of the war. Objects left over from that time may be the only witnesses of this progress, hiding secrets of the chemical industry's search for new synthetic materials. Indeed, the successful revelation of the polymeric plasticiser by MALDIMS and NMR give new insights into the advancements of the chemical industry during WWII. Analyses of other objects from this period may throw further light on this important chapter of material history. 


\title{
Competing interests
}

The authors declare that they have no competing interests.

\section{Funding}

Not applicable.

\section{Availability of data and materials}

The datasets used and/or analysed during the current study are available from the corresponding author on reasonable request.

\section{Authors' contributions}

All authors contributed to data interpretation and to finalizing the manuscript. All authors have read and approved the final manuscript.

\section{Acknowledgements}

The authors thank museum inspector Lola Wöhlk Hansen from Glud Museum for her thoughts on the raincoat. Moreover, Thomas Cox for proofreading the text and his valuable comments.

\author{
Author's information \\ ${ }^{1}$ Conservation Centre Vejle, Maribovej 10, DK-7100 Vejle, Denmark. \\ ${ }^{2}$ Department of Chemistry, University of Copenhagen, Universitetsparken 5, DK-2100 Copenhagen \\ $\varnothing$, Denmark.
}

\section{References:}


1. Jensen S: Levevilkår under besættelsen: Træk af den økonomiske og sociale udvikling i Danmark under den tyske besættelse 1940-1945. København: Gyldendal; 1971.

2. Hygebjerg-Hansen AJ. En gammel Vejle-forretning. In: Hygebjerg-Hansen AJ, editor. Vejle Textilhandlerforening - igennem 100 år. Vejle: Byhistorisk Forlag; 1997. p. 57-60.

3. Jensen HA. Regnbeklædning. In: Sterm P, editor. Textilbogen. København: Westermanns Forlag; 1946;1. p. 408-415.

4. Kjeldbæk E. Det er koldt. In: Lundbak H, editor. Spærretid. Hverdag under besættelsen 1940-45. København: Nationalmuseet; 2005. p. 56-61.

5. Shashoua Y, Skals I. Development of a conservation strategy for a collection of waterproofed military uniforms. Conserv. 2004;28:57-65.

6. Nelson ML, O'Connor RT. Relation of certain infrared bands to cellulose crystallinity and crystal latticed type. Part I. Spectra of lattice types I, II, III and of amorphous cellulose. J Appl Polym Sci. $1964 ; 8: 1311-1324$.

7. Colom X, Carrillo F: Crystallinity changes in lyocell and viscose-type fibres by caustic treatment. Eur Polym J. 2002; 38:2225-2230.

8. Schuster K: Die Rohstoffe für die Textilindustrie. Stuttgart: Konradin-Verlag; 1953.

9. Mitchell G, France F, Nordon A, Tang PL, Gibson LT: Assessment of historical polymers using attenuated total reflectance-Fourier transform infra-red spectroscopy with principal component analysis. Herit Sci. 2013;1:28.

10. Laver M. Titanium dioxide whites. In: FitzHugh EW, editor. Artists' pigments. A handbook of their history and characteristics. London: Archetype Publications; 1997. p. 295-355.

11. Bellamy LJ: The infra-red spectra of complex molecules. 3rd ed. London: Chapman and Hall; 1975. 
12. Jutier JJ, Lemieux E, Prud'Homme RE: Miscibility of polyester/nitrocellulose blends: A DSC and FTIR study. J Polym Sci Part B: Polym Phys. 1988;26:1313-1329.

13. Castle L, Mercer AJ, Gilbert J: Migration from plasticized films into foods. 5. Identification of individual species in a polymeric plasticizer and their migration into foods. Food Addit Contam. 1991;8:565-576.

14. Oriol-Hemmerlin C, Pham Q: Poly 1, 3-butylene adipate Reoplex ${ }^{\circledR}$ as high molecular weight plasticizer for PVC-based cling films - microstructure and number-average molecular weight studied by $1 \mathrm{H}$ and 13C NMR. Polym. 2000;41:4401-4407.

15. Wilson AS: Plasticisers: Selection, applications and implications. Shawbury: Rapra Technology LTD; 1996.

16. Wilson SP: Pyroxylin enamels and lacquers. Their raw materials, manufacture and application. 2nd ed. New York: D. Van Nostrand Company, Inc.; 1929.

17. Lauridsen CB, Sanyova J, Simonsen KP. Analytical study of modern paint layers on metal knight shields: The use and effect of Titanium white. Spectrochim Acta A Mol Biomol Spectrosc. $2014 ; 124: 638-45$.

18. Götze K: Chemiefasern nach dem Viskoseverfahren. 2nd ed. Berlin: Springer-Verlag; 1951.

19. Bauer R: Zellwolle siegt. Leipzig: Wilhelm Goldmann Verlag; 1941.

20. Dominik H: Vistra, das weiße Gold Deutschlands: Die Geschichte einer weltbewegenden Erfindung. Leipzig: Koehler \& Amelang; 1936.

21. Höschle G: Die deutsche Textilindustrie zwischen 1933 und 1939: Staatsinterventionismus und ökonomische Rationalität. Stuttgart: Franz Steiner Verlag; 2004.

22. Sterm P: Textilbogen. Haandbog i textil varekundskab. København: Westermanns forlag; $1946 ; 1$.

23. Drexler P: Papiergarnindustrie und Kriegswirtschaft. Würzburg: Gebrüder Memminger; 1919. 
24. Arndt P: Alte und neue Faserstoffe. 2nd ed. Berlin: Dietrich Reimer; 1918.

25. Scherner J: The beginnings of Nazi autarky policy: The 'National Pulp Programme'and the origin of regional staple fibre plants. Econ Hist Rev. 2008;61:867-895.

26. Statistics of Industrial Production 1944. Copenhagen: the Statistical Department.

27. Kraus A: Handbuch der Nitrocelluloselacke. Teil 2. Nitrocelluloselacke. Berlin-Wilmersdorf: Wilhelm Pansegrau Verlag; 1952.

28. Doolittle AK: The technology of solvents and plasticizers. New York: Wiley; 1954.

29. Standeven H: House paints, 1900-1960: History and use. Los Angeles: Getty Publications; 2011.

30. Gnamm H: Die Lösungsmittel und Weichmachungsmittel. 5th ed. Stuttgart: Wissenschaftliche Verlagsgesellschaft M.B.H.; 1946.

31. Kraus A: Handbuch der Nitrocelluloselacke. Teil 3. Weichmachungsmittel. Berlin-Wilmersdorf: Wilhelm Pansegrau Verlag; 1961.

32. Koroly JE, Beavers EM: Polymeric plasticizers-preparation and characterization of a series of terminated polyesters. Ind Eng Chem. 1953;45:1060-1063.

33. B. H: Neue Kunststoffe/ Kunststoffchemie/ Kunststoffphysik. Polymere Weichmacher. Kunstst. 1954;44 Jahrgang:257.

34. ter Meer F: Die IG Farben Industrie Aktiengesellschaft: Ihre Entstehung, Entwicklung und Bedeutung. Düsseldorf: Econ-Verlag GMBH; 1953.

35. Reinhardt C. Basic research in industry: Two case studies at IG Farbenindustrie AG in the 1920’s and 1930’s. In: Travis AS, Schröter HG Homburg E, Morris, PJT, editors. Determinants in the Evolution of the European Chemical Industry, 1900-1939. Dordrecht: Kluwer Academic Publishers; 1998. p. 67-88. 
36. Kaufmann M: The first century of plastics - celluloid and its sequel. London: Chameleon Press Ltd.; 1963.

37. Braun D: PVC—origin, growth, and future. J Vinyl Add Tech. 2001;7:168-176.

38. Morris PJ. Ambros, Reppe, and the emergence of heavy organic chemicals in Germany, 19251945. In: Travis AS, Schröter HG, Homburg E, Morris, PJT, editors. Determinants in the Evolution of the European Chemical Industry, 1900-1939. Dordrecht: Kluwer Academic Publishers; 1998. p. 89-122.

39. Reppe W: Neue Entwicklungen auf dem Gebiete der Chemie des Acetylens und Kohlenoxyds. Berlin: Springer-Verlag; 1949.

40. Weitz HM, Hartig J. Butadien. In: Bartholomé E, Biekert E, Hellmann H, editors. Ullmanns Encyklopädie der technischen Chemie. Weinheim: Verlag Chemie; 1975. p. 1-18.

41. Petzina D: Autarkiepolitik im Dritten Reich. Der nationalsozialistische Vierjahresplan. Stuttgart: Deutsche Verlags-Anstalt; 1968.

42. Treue W: Hitlers Denkschrift zum Vierjahresplan 1936. Vierteljahrsh Zeitgesch. 1955;3:184203.

43. Wünsch FI: Das Werk Hüls: Geschichte der Chemische Werke Hüls AG in Marl von 1938 bis 1949. Tr Z Firmengescht Unternehmerbiogr. 1964;9:70-79.

44. Hayes P: Industry and ideology: IG Farben in the Nazi era. 2nd ed. Cambridge: University Press; 2001. 

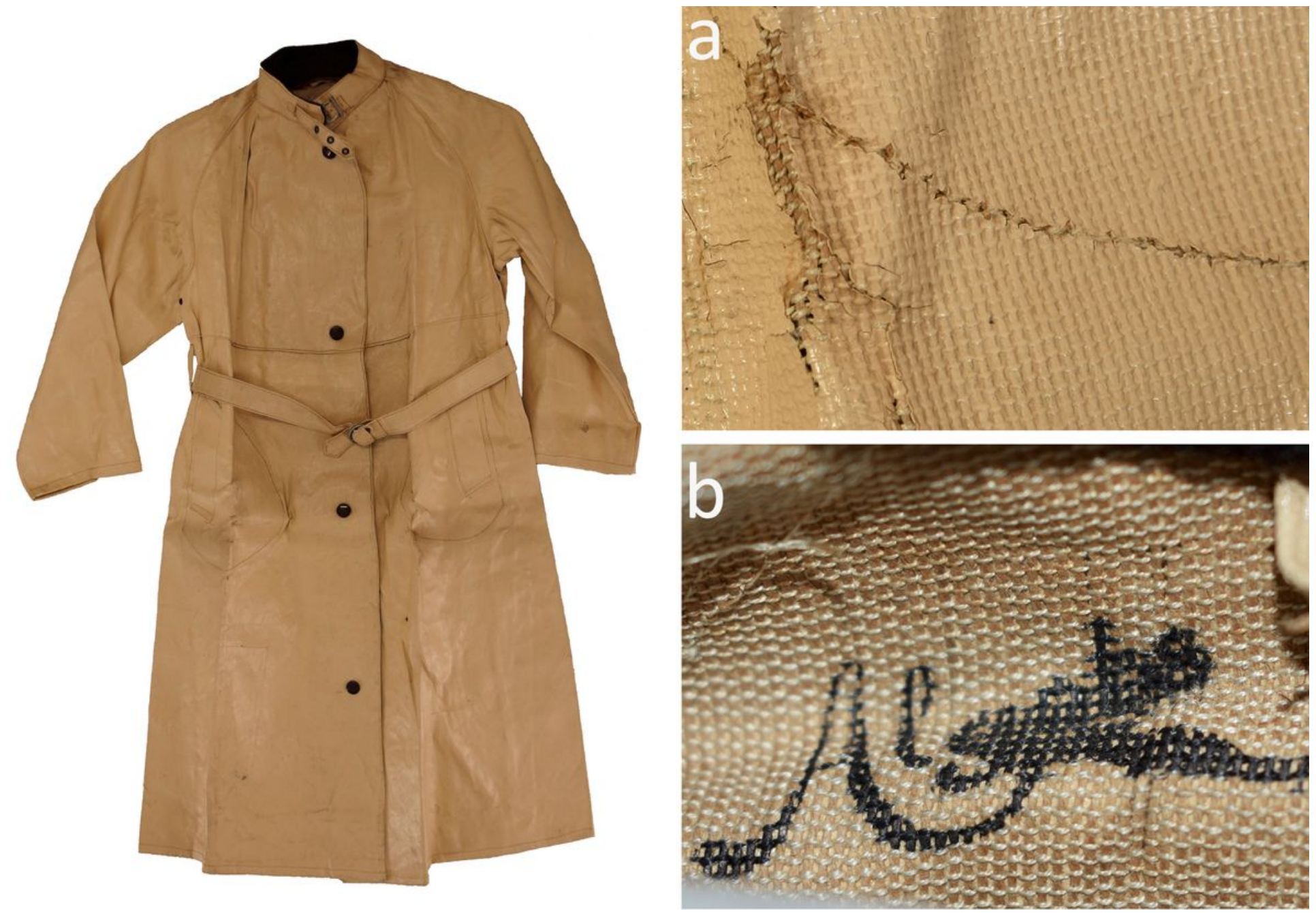

\section{Figure 1}

The raincoat from Al Hansen and details of a the coating by the non-sealed seam of the pocket and $b$ the fabric of the inside by the smeared trademark showing the white warp and the brown weft. 


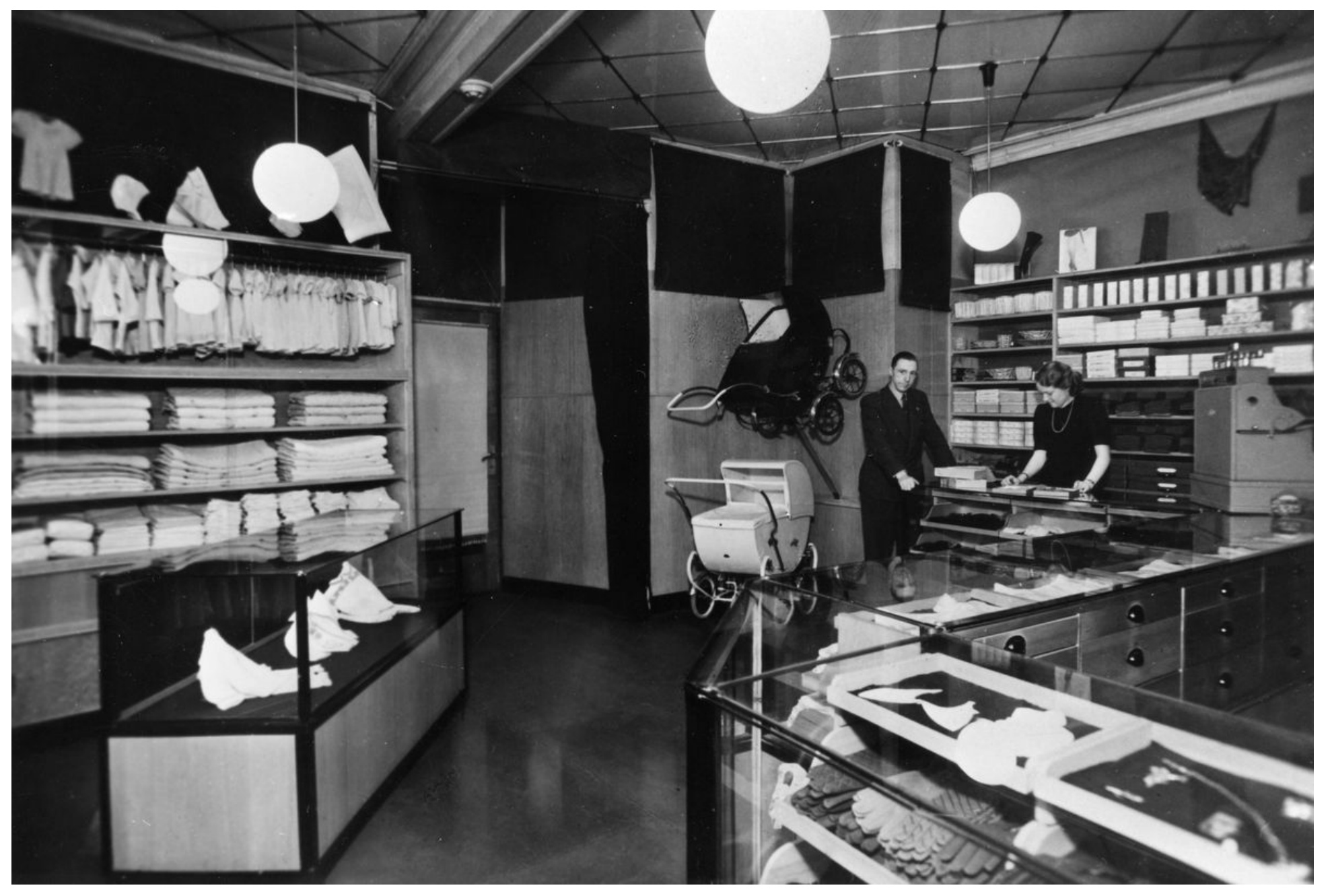

Figure 2

Interior view of the clothing store Al Hansen, 1943. Photographer unknown. Photo: Vejle City Archives. 


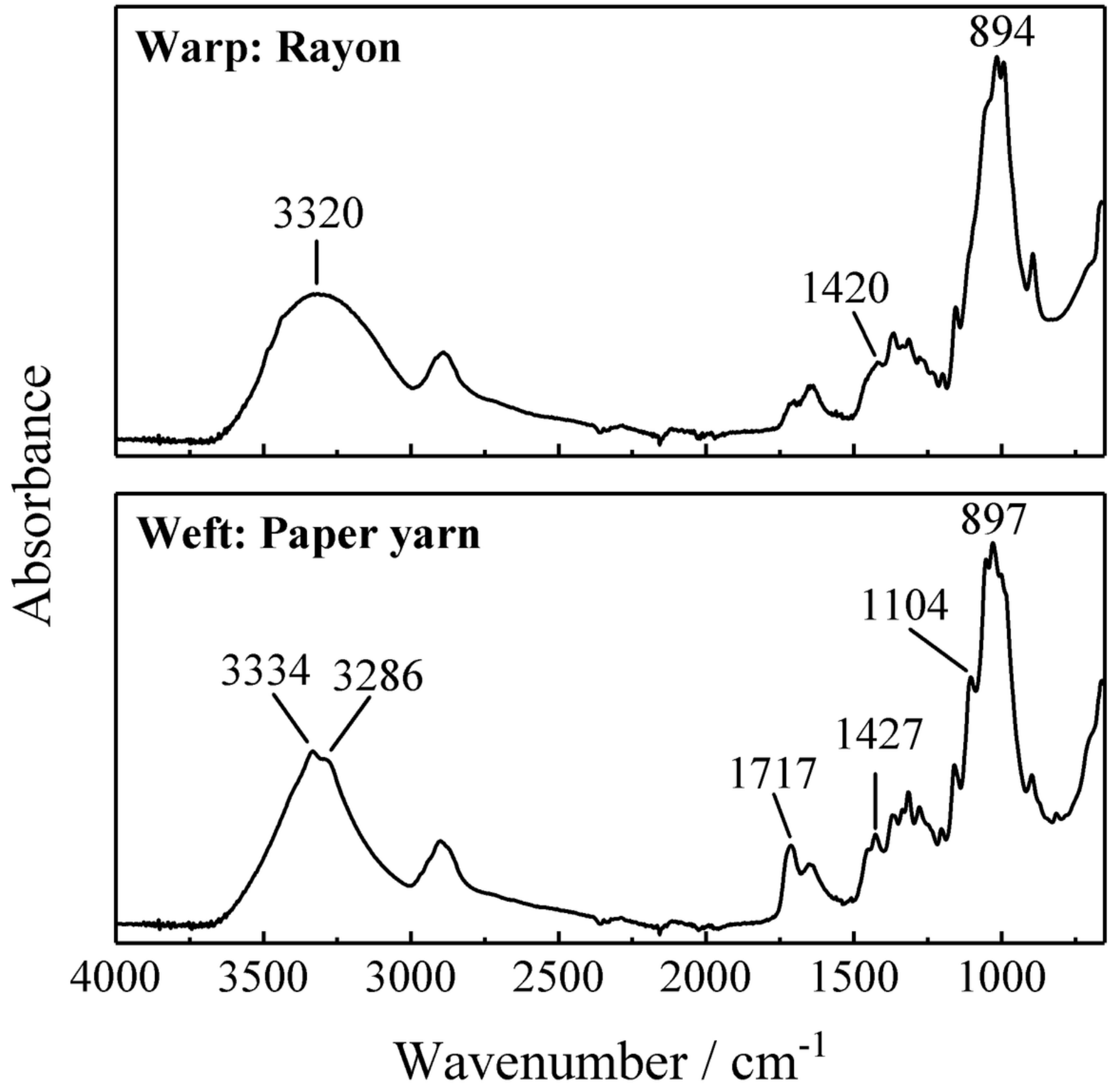

Figure 3

ATR-FTIR spectra of Rayon and paper yarn. 


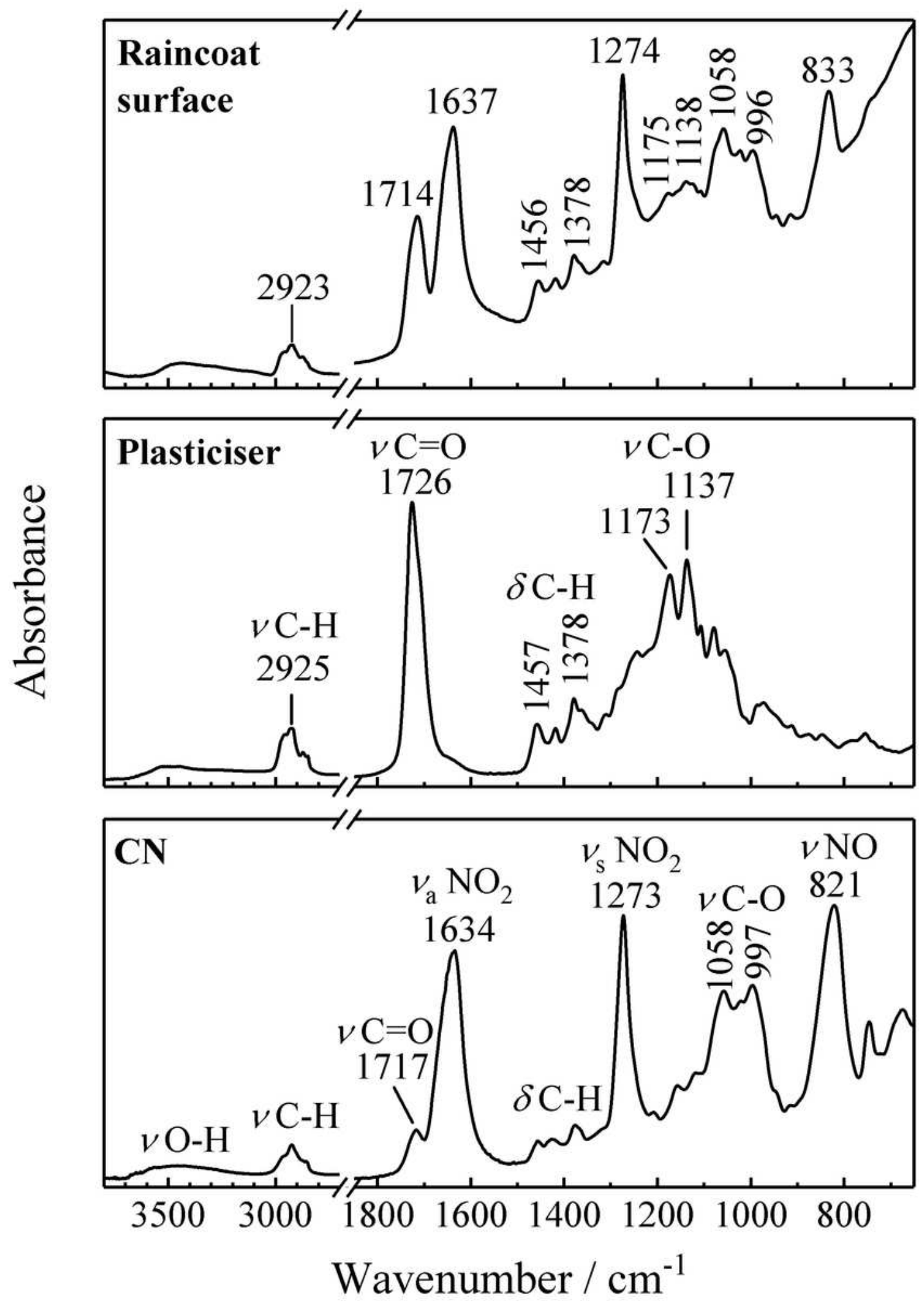

Figure 4

ATR-FTIR spectra of the raincoat surface showing the characteristic frequencies of $\mathrm{CN}$ and the plasticiser and below the extracted plasticiser and $\mathrm{CN}$ with assignment of the frequencies. 

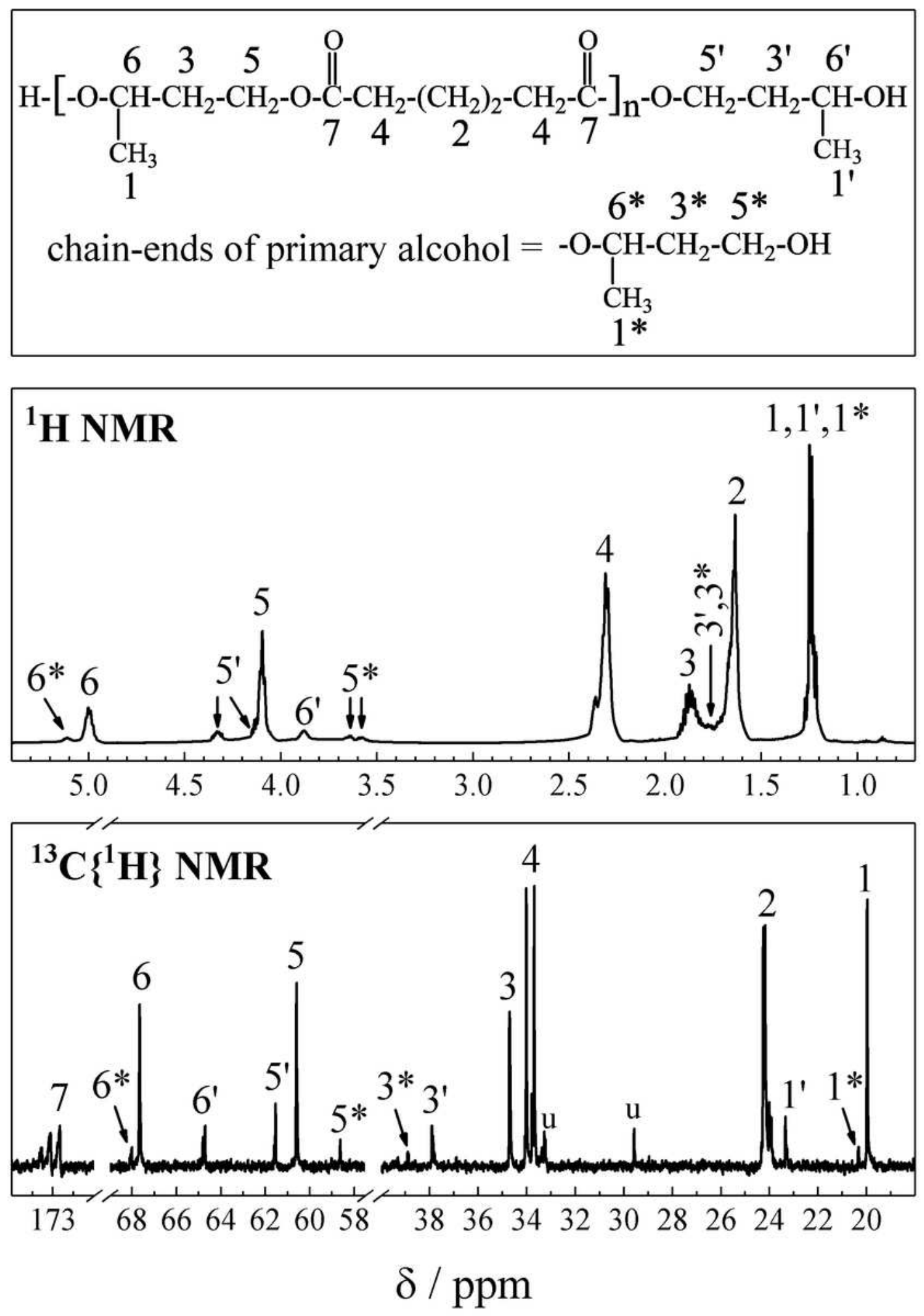

Figure 5

$1 \mathrm{H}$ and $13 \mathrm{C}\{1 \mathrm{H}\}$ NMR spectra of the extracted plasticiser in $\mathrm{CDCl} 3$ identifying it as poly(1,3-butylene) adipate. The structure of the two major diol-terminated species is shown at top together with the molecule numbering scheme for the characterization ( $u=$ unknown). 


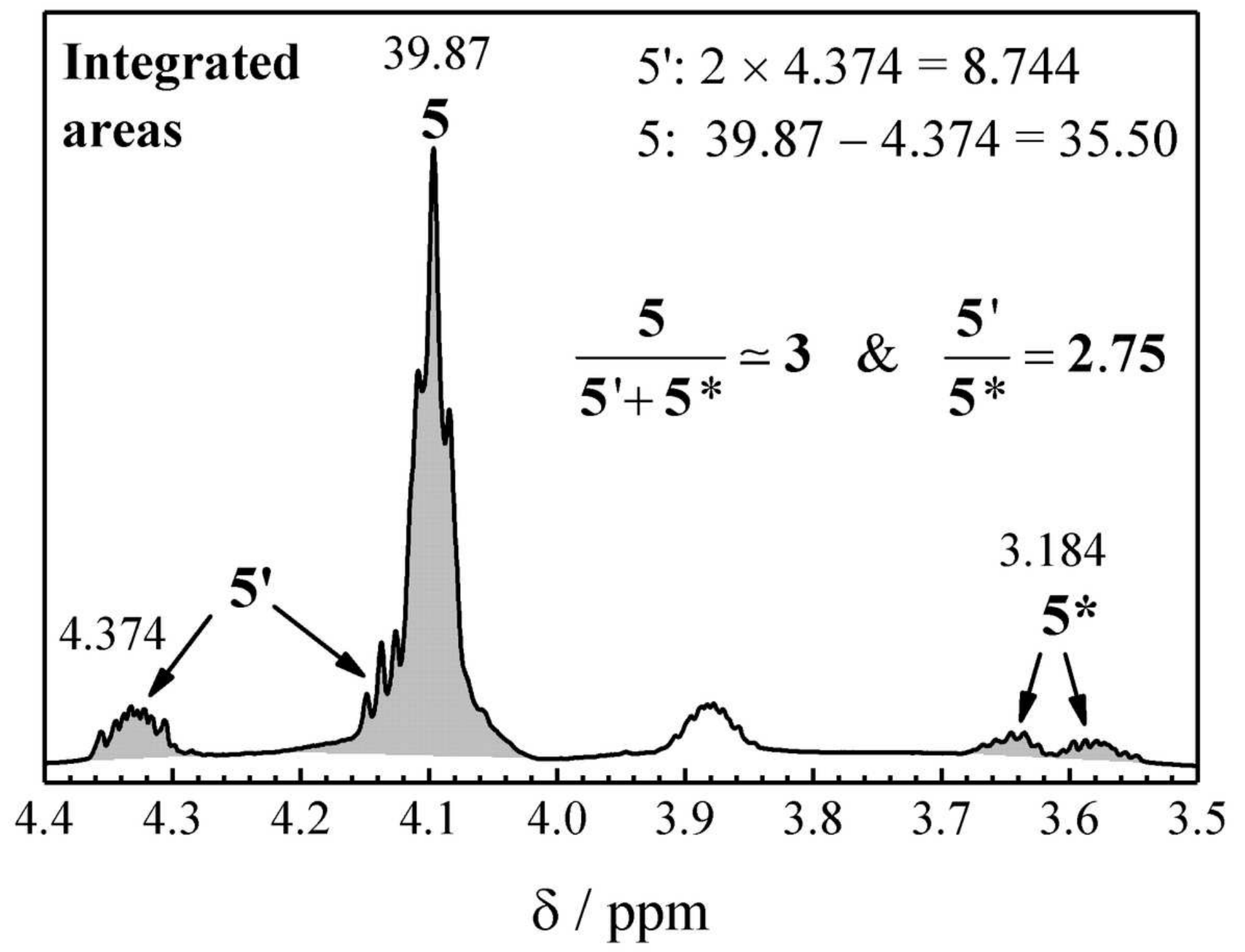

Figure 6

Ratio of the integrated areas of the in-chain esterified primary alcohol (5) and its mono-esterified endgroups (5' and $\left.5^{\star}\right)$. 


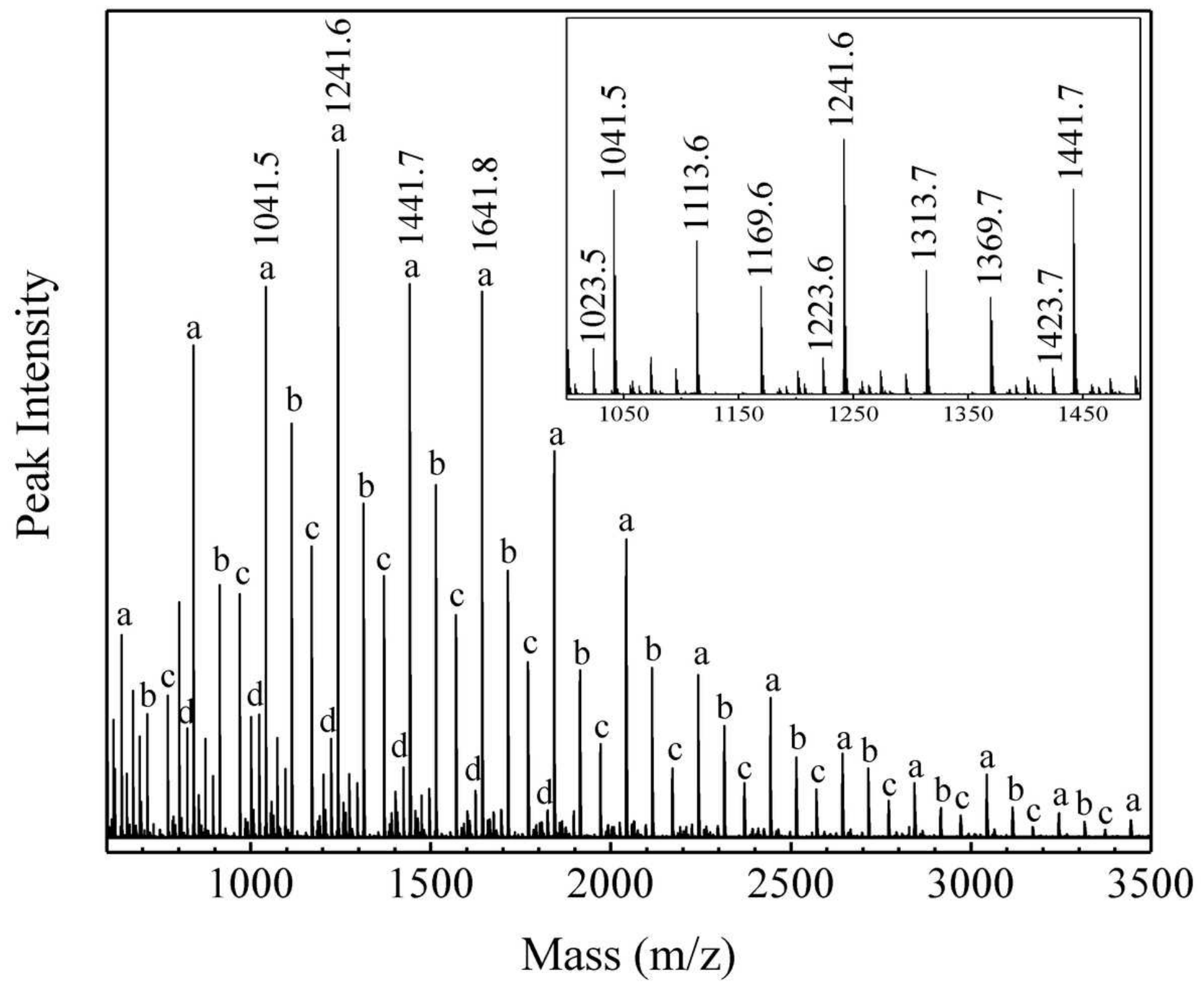

Figure 7

MALDI-MS spectrum of the plasticiser with insert of enlarged area from 1000 to $1500 \mathrm{~m} / \mathrm{z}$ units. Structural assigments of the ion peaks, and the oligomer repeat units (n), are seen in Fig. 8. 


\begin{tabular}{|c|c|}
\hline Structure (M) and species notation a - d & $(\mathrm{M}+\mathrm{Na})^{+}$ \\
\hline 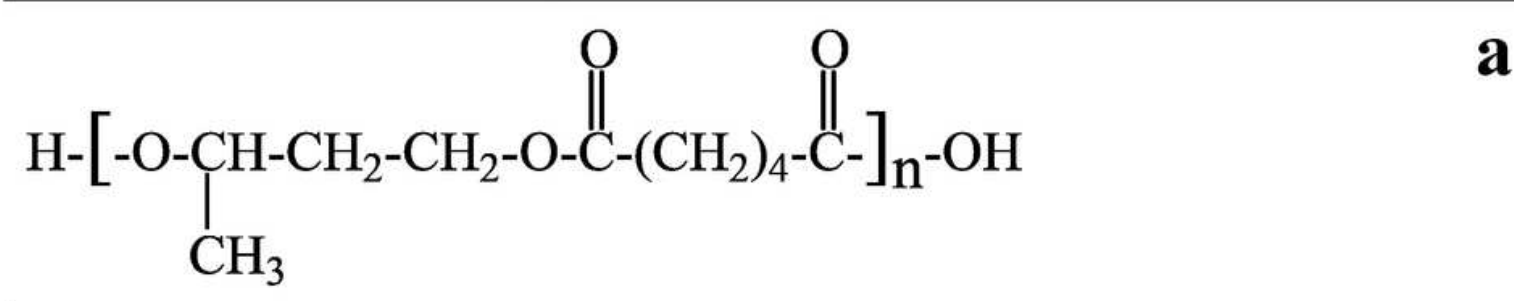 & $\begin{array}{l}1041.5(\mathrm{n}=5) \\
1241.6(\mathrm{n}=6) \\
1441.7(\mathrm{n}=7) \\
1641.8(\mathrm{n}=8)\end{array}$ \\
\hline$\underset{\mathrm{H}-\left[-\mathrm{O}-\mathrm{CH}-\mathrm{CH}_{2}-\mathrm{CH}_{2}-\mathrm{O}-\mathrm{C}-\left(\mathrm{CH}_{2}\right)_{4}-\mathrm{C}-\right]_{\mathrm{n}}-\mathrm{O}-\mathrm{CH}_{2}-\mathrm{CH}_{2}-\mathrm{CH}-\mathrm{OH}}{\stackrel{\mathrm{O}}{\mathrm{C}}}$ & $\begin{array}{l}1113.6(\mathrm{n}=5) \\
1313.7(\mathrm{n}=6) \\
1513.8(\mathrm{n}=7) \\
1713.9(\mathrm{n}=8)\end{array}$ \\
\hline$\stackrel{\mathrm{O}}{\mathrm{O}} \stackrel{\mathrm{O}-\mathrm{C}-\left(\mathrm{CH}_{2}\right)_{4}-\mathrm{C}-\left[-\mathrm{O}-\mathrm{CH}-\mathrm{CH}_{2}-\mathrm{CH}_{2}-\mathrm{O}-\mathrm{C}-\left(\mathrm{CH}_{2}\right)_{4}-\mathrm{C}-\right]_{\mathrm{n}}-\mathrm{OH}}{\mathrm{O}}$ & $\begin{array}{l}1169.6(\mathrm{n}=5) \\
1369.7(\mathrm{n}=6) \\
1569.8(\mathrm{n}=7) \\
1769.9(\mathrm{n}=8)\end{array}$ \\
\hline$-\left[-\mathrm{O}-\mathrm{CH}-\mathrm{CH}_{2}-\mathrm{CH}_{2}-\mathrm{O}-\mathrm{C}-\left(\mathrm{CH}_{2}\right)_{4}-\mathrm{C}-\right]_{\mathrm{CH}}$ & $\begin{array}{l}1023.5(\mathrm{n}=5) \\
1223.6(\mathrm{n}=6) \\
1423.7(\mathrm{n}=7) \\
1623.8(\mathrm{n}=8)\end{array}$ \\
\hline
\end{tabular}

Figure 8

Structural assignments of ion peaks shown in Fig. 9 and the molar masses of the oligomer repeat units (n). 


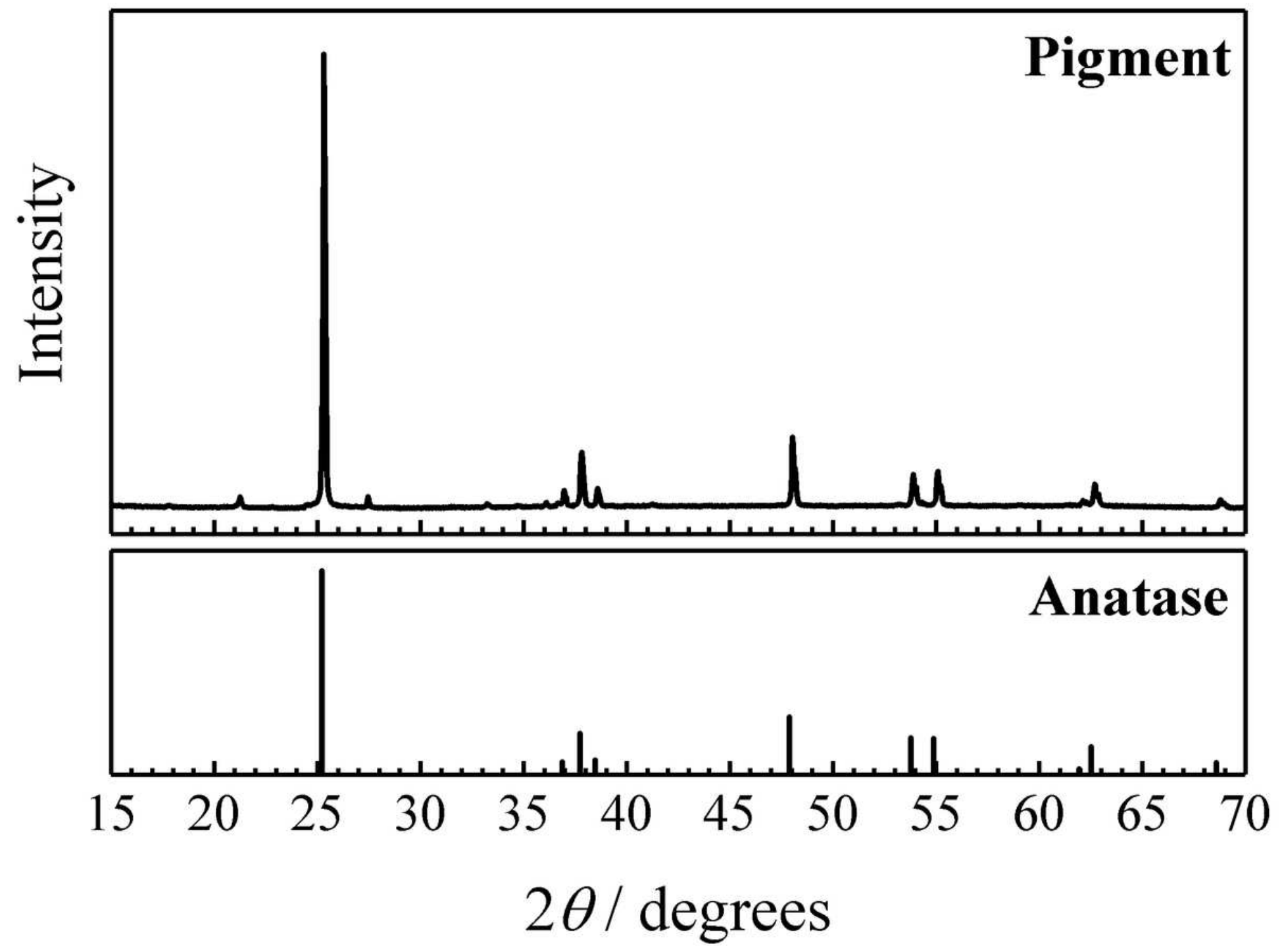

Figure 9

PXRD of the pigment and anatase. 